Document downloaded from:

http://hdl.handle.net/10251/145998

This paper must be cited as:

Espinosa, M.; Blay, G.; Cardona, L.; Fernández, I.; Muñoz Roca, MDC.; Pedro, J. (2018). Lanthanum-pyBOX complexes as catalysts for the enantioselective conjugate addition of malonate esters to beta-gamma-unsaturated alfa-ketimino esters. Journal of Coordination Chemistry. 71(6):864-873. https://doi.org/10.1080/00958972.2018.1437422

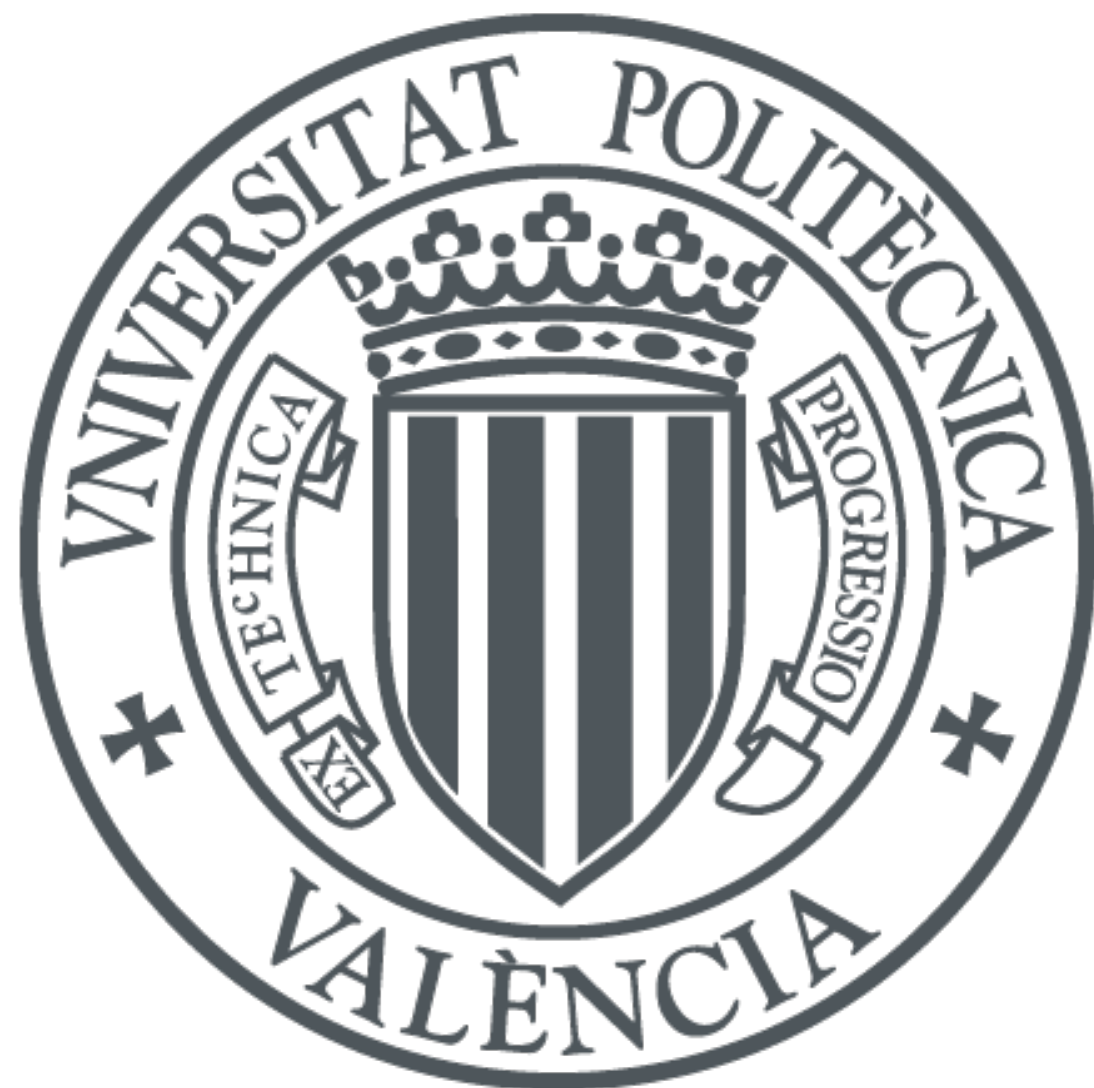

The final publication is available at

https://doi.org/10.1080/00958972.2018.1437422

Copyright Taylor \& Francis

Additional Information

"This is an Accepted Manuscript of an article published by Taylor \& Francis in Journal of Coordination Chemistry on 2018, available online: https://doi.org/10.1080/00958972.2018.1437422." 


\section{Lanthanum-pyBOX complexes as catalysts for the enantioselective conjugate addition of malonate esters to $\beta, \gamma$-unsaturated $\alpha$-ketimino esters}

MIGUEL ESPINOSA $\uparrow$, GONZALO BLAY*†, LUZ CARDONA $\uparrow$, ISABEL FERNÁNDEZ†, M. CARMEN MUNOZ + and JOSE R. PEDRO*†

†Department de Química Orgànica, Facultat de Química, Universitat de València, C/ Dr. Moliner 50, E-46100 Burjassot (València), Spain

†Departament de Física Aplicada, Universitat Politècnica de València, Camí de Vera s/n, E-46071 València, Spain

Dedicated to Professor Juan Faus, Universitat de València, on the occasion of his retirement.

In this paper we report the application of chiral complexes of La(III) with pyBOX ligands as Lewis acid catalysts in the conjugate addition of malonic esters to $N$-tosyl imines derived from $\beta, \gamma$-unsaturated $\alpha$-keto esters to give the corresponding chiral $\alpha, \beta$-dehydroamino esters. pyBOX complexes with $\mathrm{La}(\mathrm{III}), \mathrm{Yb}(\mathrm{III}), \mathrm{Sc}(\mathrm{III})$ and $\mathrm{In}(\mathrm{III})$ triflates were assessed in this reaction but only $\mathrm{La}$ (III) showed good activity and enantioselectivity, while $\mathrm{Yb}$ (III) provided the expected product with low yield and stereoselectivity, and the Sc(III) and In(III) complexes were completely inactive. The complex of $\mathrm{La}(\mathrm{OTf})_{3}$ with the diphenyl-pyBOX ligand prepared in situ provided the best results and allowed obtaining chiral $\alpha, \beta$-dehydroamino esters 3 with excellent yields, $E: Z$ diastereomeric ratios (29:71 to 99:1) and high enantiomeric excesses (20-95\%). The reaction could be applied to imines having a substituted aromatic ring or a heterocycle attached to the double bond, although the presence of electron-withdrawing groups on the aromatic ring was detrimental for stereoselectivity. The reaction products were obtained with the $S$ configuration at the stereogenic center and the $Z$ configuration at the enamine double bond as determined by NOESY experiments and X-ray analysis. Based on the experimental results a stereochemical model involving a nine-coordinate $\mathrm{La}(\mathrm{III})$ species has been proposed.

Keywords: Asymmetric catalysis; Lanthanide complexes; Michael addition; Enantioselectivity

*Corresponding authors. Email: gonzalo.blay@uv.es (G. Blay); jose.r.pedro@uv.es (J.R. Pedro) 


\section{Introduction}

The coordination chemistry of rare earth metals (including the Group 3 metals scandium, yttrium, and lanthanum alongside the $4 \mathrm{f}$ elements) is strongly dominated by the most common and stable +3 oxidation state, with less common +4 oxidation state available for $\mathrm{Ce}, \mathrm{Pr}$ and $\mathrm{Tb}$ and +2 oxidation state available for $\mathrm{Sm}, \mathrm{Eu}$ and $\mathrm{Yb}$ [1]. Because of their identical outer shell electron configuration $\left(5 s^{2} 5 p^{6}\right.$ except for La), rare earth metals often have similar properties, although the different ionic radii may determine the suitability of a ligand to a particular metal, the coordination number and the charge concentration, giving rise to subtle differences within the element series. The limited accessibility of oxidation states other than the Ln(III) limits the catalytic applications of these elements in reactions where, for example, oxidative addition and/or reductive elimination are key steps in the catalytic cycle. In contrast, lanthanides have shown exceptional capability as Lewis acids [2]. Lanthanides have hard Lewis acidity and show strong affinity for heteroatoms such as nitrogen and oxygen in organic molecules, thus enabling strong activation of functional groups such as carbonyl or imines. In addition, lanthanides are characterized by large coordination numbers (up to nine) compared with other common Lewis acidic metals (such as Ti, Al, B and Sn), which allows lanthanides to keep their Lewis acidity even after being coordinated by a ligand, which is especially important with reactions involving polychelating substrates. In the last decades, a number of complexes of lanthanides with chiral ligands have been used as Lewis acid catalysts in asymmetric reactions [3]. The 2,6-bis(oxazolinyl)-pyridine (pyBOX) ligand has been widely used in asymmetric catalytic applications of the lanthanides and other metals [4]. This tridentate ligand adopts a planar arrangement of the coordinating nitrogens, with the trans $\mathrm{N}$-metal-N angle being significantly smaller than $180^{\circ}$. This coordination mode opens up the metal center to higher coordination numbers at the same time as the highly rigid and sterically imposing pyBOX ligand framework creates a well-defined chiral space. Besides their potential applications in imaging and lighting due to luminescence [5], lanthanide-pyBOX complexes have been used as catalysts in different enantioselective reactions such as $\alpha$-amination of carbonyl compounds [6], 1,3-dipolar cycloadditions [7], Diels-Alder reactions [8], Mukaiyama-Aldol and Mukaiyama-Michael additions [9] and the cyanation of carbonyl compounds [10]. 
On the other hand, non-proteinogenic $\alpha, \beta$-dehydroamino acid derivatives are often found in natural products produced by bacteria, fungi, marine organisms and plants, and play an important role in the biosynthesis of other non-proteinogenic amino acids [11]. Some of these compounds have antibiotic and other interesting activities [12], while others are used as starting materials in the synthesis of natural and unnatural $\alpha$-amino acids as well as in the synthesis of heterocyclic compounds [13]. Because of these properties, there is growing interest in the development of efficient synthetic methods for this kind of compound. Recently, the conjugate addition of nucleophiles to $\beta, \gamma$-unsaturated $\alpha$-keto esters has emerged as a new strategy for the preparation of $\beta$-dehydroamino esters [14]. Furthermore, our group has shown that 1,3-dicarbonyl compounds are prone to catalysis by La(III)-pyBOX, which efficiently promoted the enantioselective conjugate addition of malonate esters to unsaturated ketimines to give chiral enamines [15]. By considering both strategies together, we envisioned that chiral $\alpha, \beta$-dehydroamino esters 3 may be obtained in an enantioselective fashion by achieving the conjugate addition of malonate esters 1 to imines $\mathbf{2}$ derived from $\beta, \gamma$-unsaturated $\alpha$-keto esters (scheme 1).

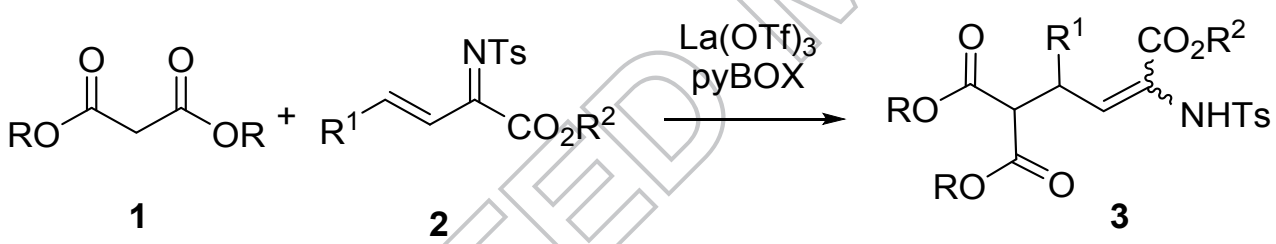

Scheme 1. Conjugate addition of malonate esters to $N$-tosyl imines derived from $\beta, \gamma$-unsaturated $\alpha$-keto esters.

\section{Materials and methods}

\subsection{General procedures}

Reactions were carried out under nitrogen in Schlenk tubes oven-dried overnight at $120{ }^{\circ} \mathrm{C}$. Reactions were monitored by TLC analysis using Merck Silica Gel 60 F-254 thin layer plates. Flash column chromatography was performed on Merck silica gel 60, 0.040-0.063 mm. 


\subsection{Reagents and solvents}

Commercial reagents were used as purchased. Dichloromethane was distilled from $\mathrm{CaH}_{2} .4 \AA$ Molecular sieves (8-12 mesh, beads Aldrich 208604) for enantioselective reactions were dried at the flame under vacuum (oil pump) and stored in a closed flask and used within a week. Imines 2 were prepared according to procedures described in the literature [14d].

\subsection{Characterization of the reaction products}

Melting points were determined in capillary tubes in a Büchi M-560 instrument.

NMR spectra were run at $300 \mathrm{MHz}$ for ${ }^{1} \mathrm{H}$ and at $75 \mathrm{MHz}$ for ${ }^{13} \mathrm{C}$ NMR in a Bruker Avance 300 DPX spectrometer using residual nondeuterated solvent $\left(\mathrm{CHCl}_{3}\right)$ as internal standard ( $\delta 7.26$ and $77.0 \mathrm{ppm}$, respectively). Chemical shifts are given in ppm. The carbon type was determined by DEPT experiments.

High resolution mass spectra (ESI) were recorded on a Waters Q-TOF Premier spectrometer equipped with an electrospray source with a capillary voltage of $3.3 \mathrm{kV}$ (ESI).

Specific optical rotations were measured in $\mathrm{CHCl}_{3}$ solutions with a Perkin-Elmer 241 polarimeter using sodium light (D line $589 \mathrm{~nm}$ ) in a $1 \mathrm{dm}$ cell. Concentrations are given in $\mathrm{g} / 100 \mathrm{~mL}$.

Chiral HPLC analyses were performed in a Hitachi Elite Lachrom chromatograph equipped with a Hitachi L-4500 UV diode-array detector using chiral stationary phase columns from Daicel or Phenomenex.

X-ray data for $\mathbf{3 b}$ w were collected on an Enraf Nonius Kappa CCD apparatus equipped with a graphite monochromator and $\mathrm{Mo} \mathrm{K \alpha}(\lambda=0.71073 \AA)$ radiation. The structures were solved by using direct methods with SHELXS-2014 and refined by using full matrix least squares on F2 with SHELXL-2014 [16].

\subsection{General procedure for the enantioselective conjugate addition of diethyl malonate to $\alpha, \beta$-unsaturated $N$-tosyl imines 2}

$\mathrm{La}(\mathrm{OTf})_{3}(14.7 \mathrm{mg}, 0.025 \mathrm{mmol})$ was dried in a Schlenk tube under vacuum. pyBOX1 (9.24 mg, $0.025 \mathrm{mmol})$ was added and the tube was filled with nitrogen. $\mathrm{CH}_{2} \mathrm{Cl}_{2}(1.1 \mathrm{~mL})$ was added via syringe and the mixture was stirred for $30 \mathrm{~min}$. A solution of imine $2(0.25 \mathrm{mmol})$ dissolved in dry $\mathrm{CH}_{2} \mathrm{Cl}_{2}(1.1 \mathrm{~mL})$ was added via syringe, followed by $4 \AA \mathrm{MS}(110 \mathrm{mg})$ and diethyl malonate 
$(92 \mu \mathrm{L}, 0.63 \mathrm{mmol})$. The mixture was stirred at room temperature for the indicated time and chromatographed on silica gel eluting with hexane/EtOAc mixtures to give 3 .

Racemic compounds for comparative purposes were prepared following the same procedure, using $\mathrm{La}(\mathrm{OTf})_{3}$-pyBOX (rac) at $40{ }^{\circ} \mathrm{C}$.

\section{Results and discussion}

\subsection{Optimization of reaction conditions}

A preliminary screening of catalytic complexes based on trivalent metal salts and pyBOX ligands (figure 1) was undertaken using the reaction between dimethyl malonate $(\mathbf{1 a}, \mathrm{R}=\mathrm{Me}$ ) and the $\alpha, \beta$-unsaturated $N$-tosyl imine $2 \mathbf{a}\left(\mathrm{R}^{1}=\mathrm{Ph}, \mathrm{R}^{2}=\mathrm{Et}\right)$ in the presence of $4 \AA \mathrm{MS}$ and dichloromethane as the solvent (table 1).

The complexes of $\mathrm{Sc}(\mathrm{OTf})_{3}$ or $\operatorname{In}(\mathrm{OTf})_{3}$ with pyBOX1 were completely inactive and no significant progress of the reaction was observed after $46 \mathrm{~h}$ (table 1, entries 3 and 4) while the complex with $\mathrm{Yb}(\mathrm{OTf})_{3}$ promoted a sluggish reaction and provided the expected product 3 aa with low yield, fair diastereomeric ratio and low $30 \%$ ee (table 1, entry 2 ). The pyBOX1$\mathrm{La}(\mathrm{OTf})_{3}$ complex was more active and, after 16 h, gave $3 \mathbf{a a}$ in excellent yield, with outstanding diastereoselectivity and $86 \%$ ee (table 1 , entry 1 ). Other pyBOX ligands were tested in combination with $\mathrm{La}(\mathrm{OTf})_{3}$ but none of them improved the results obtained with pyBOX1 (table 1, entries 5-8). The pore size in the molecular sieves seemed not to have any effect on the performance of the reaction and either $3 \AA$ or $5 \AA \mathrm{MS}$ afforded similar results as $4 \AA \mathrm{MS}$ (table 1, entries 9 and 10). Next we studied different solvents. Unfortunately, none of them produced any upturn in the results; only diethyl ether performed similarly to dichloromethane (table 1, entries 11-16). The influence of the alkoxy group in the malonate ester was also assessed. Slightly enhanced stereoselectivity was obtained with diethyl malonate $(\mathbf{1 b}, \mathrm{R}=\mathrm{Et}$, table 1, entry 17), while diisopropyl malonate (1c, $\mathrm{R}=i \operatorname{Pr})$ gave the reaction product with only $73 \%$ ee (table 1, entry 18). Surprisingly, the use of diethyl ether with these two esters was deleterious, unlike with dimethyl malonate (table 1, entries 19 and 20). Finally, a decrease of temperature to $0{ }^{\circ} \mathrm{C}$ resulted in a decrease in the reaction rate and a slight loss of optical purity in the resulting enamine (table 1 , entry 22 ).

Finally, it is worth remarking that 3aa was obtained as a single diastereomer with excellent diastereoselectivity $(\mathrm{dr}=99: 1)$ favoring the $Z$ configuration in the double bond. 
The reaction of dimethyl malonate (1a) and imine 2 a catalyzed by $\mathrm{La}(\mathrm{OTf})_{3}$ in the absence of a pyBOX ligand in dichloromethane at room temperature was incomplete after $24 \mathrm{~h}$, providing the product resulting from 1,2-addition of dimethyl malonate to the imine $\mathrm{C}-\mathrm{N}$ double bond. After increasing the temperature to $40{ }^{\circ} \mathrm{C}$ the mixture evolved to give $\mathbf{3 a a}$ as a diastereomer mixture ( $E: Z=74: 26$ ) favoring the $E$ enantiomer (table 1, entry 23).

\subsection{Scope of the reaction}

With the optimized conditions in hand, we studied the scope of the reaction with different imines 2. Since diethyl malonate gave better results than dimethyl or diisopropyl malonate, most of the study was restricted to this nucleophile. The results are gathered in table 2 .

Different imines 2 having aromatic substitution at the double bond ( $\gamma$-carbon) of the unsaturated ketimino ester were suitable substrates for the reaction (table 2, entries 1-10). In general the reaction took place with excellent diastereoselectivity favoring the formation of the isomer having the $Z$ configuration at the enamine double bond, with $E / Z$ ratios higher than 10:90, except in the case of nitro derivative $\mathbf{3 b j}$ that was obtained as an $E / Z$ 29:71 mixture (table 2, entry 10). High enantiomeric excesses above $86 \%$ were obtained when $\mathrm{R}^{1}$ was a phenyl group substituted with either neutral $(\mathrm{Me})$ or electron-donating $(\mathrm{MeO})$ substituents at any of the positions (table 2, entries 2, 5 and 8). The best enantioselectivity was obtained when $\mathrm{R}^{1}$ was a 2- or 3-clorophenyl ring (table 2 , entries 6 and 9). Nevertheless, when a nitro group is attached to the aromatic ring, a dramatic drop in the enantiomeric excess (table 2, entries 4, 7 and 10) was observed. The substituent $\mathrm{R}^{1}$ can also be a heteroaromatic ring (table 2, entry 11); the corresponding enamine was obtained with excellent diastereoselectivity and still $84 \%$ ee. Finally, the alkoxy group in $\mathbf{2}$ was also amenable to variation. Imines $\mathbf{2}$ and $\mathbf{2 m}$ derived from methyl or isopropyl keto esters gave the corresponding products with excellent diastereo- and enantioselectivity (table 2, entries 12 and 13).

\subsection{Stereochemical outcome}

The stereochemistry of the double bond in compounds $\mathbf{3}$ was assigned as $Z$ on the basis of NOESY experiments carried out with 3 be (see Supporting Information). The spectrum showed an interaction between the $\mathrm{NH}$ enamine proton at $\delta 6.73$ and the benzylic proton at $\delta 4.62$, which is only possible if the double bond has the $Z$ configuration. Furthermore, $\mathbf{3 b l}$ could be 
crystallized and subjected to X-ray analysis [17], which allowed us to confirm the geometry of the double bond as $Z$ (figure 2). The absolute stereochemistry of $\mathbf{3 b l}$ with the $S$ configuration at the stereogenic center was established on the basis of a Flack parameter value of -0.03(5) obtained after structure refinement [18]. The absolute stereochemistries for the other obtained enamines 3 were assigned by analogy upon the assumption of a uniform stereochemical pathyay.

These results indicate the preference of the malonate to approach from the $R e$ face of the double bond of the unsaturated imine 2. Taking into account previous studies on La(III)-pyBOXcatalyzed reactions [8b-c, 9b], we propose participation of a nine-coordinate $\mathrm{La}(\mathrm{III})$ species with the imine ketoester 2 forming a chelate and the 1,3-dicarbonyl compound mono- (a) or dicoordinated (b) to the metal ion (figure 3). In this complex, the unsaturated imine 2, in its s-cis conformation would be oriented to avoid the steric interaction of the $R$ and tosyl groups with the phenyl group of the ligand, thus leading to the conjugate addition product 3 having the $S$-configuration at the stereogenic center and the $Z$-geometry at the double bond.

\section{Conclusion}

We have shown that $\mathrm{La}(\mathrm{III})-$ pyBOX complexes can catalyze the enantioselective conjugate addition of malonate ester derivatives to $N$-tosyl $-\beta, \gamma$-unsaturated $\alpha$-ketimino esters. The corresponding complex of $\mathrm{La}(\mathrm{OTf})$, with the diphenyl-pyBOX ligand delivered the expected chiral $\alpha, \beta$-dehydroamino esters 3 with excellent yields, diastereomeric ratios and high enantiomeric excesses. In all the cases, the reaction delivered the products with the $Z$ configuration at the enamine double bond and the $S$ configuration at the stereogenic center, as determined by NOESY experiments and X-ray analysis. Based on the experimental results a stereochemical model has been proposed.

\section{Acknowledgements}

Financial support (CTQ2013-47494-P) from the Ministerio de Economía y Competitividad (MINECO-Gobierno de España). M.E. acknowledges the Generalitat Valenciana for a predoctoral grant. Access to NMR and MS facilities from the Servei Central de Suport a la Investigació Experimental (SCSIE)-UV is also acknowledged. 


\section{References}

[1] D.A. Atwood (Ed.), The Rare Earth Elements, Fundamentals and Applications, John Wiley and Sons, Chichester (2012).

[2] For reviews see: (a) M. Shibasaki, K. Yamada, N. Yoshikawa. In Lewis Acids in Organic Synthesis, H. Yamamoto (Ed.), Vol. 2, 1st Edn., p. 911, Wiley-VCH, Weinheim (2002). (b) Y. Mori, S. Kobayashi, Rare Earth Elements, D.A. Atwood (Ed.), John Wiley and Sons, p. 437, Chichester (2012). (c) U. Ladziata, ARKIVOK, 307 (2014). (d) T. Kitanosono, S. Kobayashi. Adv. Synth. Catal., 355, 3095 (2013). For recent examples see: (e) E. Quaranta. Appl. Catal. B, 206, 233 (2017). (f) A.O. Terentev, A. Vil, E.S. Gorlov, G.I. Nikishin, K.K. Pivnitsky, W. Adam. J. Org. Chem., 81, 810 (2016). (g) S.D. Bennett, B.A. Core, M.P. Blake, S.J.A. Pope, P. Mountford, B.D. Ward. Dalton Trans., 43, 5871 (2014). (h) M. Hatanaka, K. Morokuma. J. Am. Chem. Soc., 135, 13972 (2013). (i) H. Komai, T. Yoshino, S. Matsunaga, M. Kanai. Synthesis, 44, 2185 (2012). (j) T. Yukawa, B. Seelig, Y. Xu, H. Morimoto, S. Matsunaga, A. Berkessel, M. Shibasaki. J. Am. Chem. Soc., 132, 11988 (2010). (k) H. Mihara, Y. Xu, N.E. Shepherd, S. Matsunaga, M. Shibasaki. J. Am. Chem. Soc., 131, 8384 (2009).

[3] For reviews see: (a) K. Mikami, M. Terada, H. Matsuzawa. Angew. Chem. Int. Ed., 41, 3554 (2002). (b) M. Shibasaki, N. Yoshikawa. Chem. Rev., 102, 2187 (2002). (c) S. Matsunaga, M. Shibasaki. Chem. Commun., 50, 1044 (2014). (d) J. Comelles, M. Moreno-Mañas, A. Vallribera. ARKIVOC, 207 (2005). (e) M.J. Allen. Synlett, 27, 1310 (2016). For some representative examples see: (f) K. Fu, J. Zhang, L. Lin, J. Li, X. Liu, X. Feng. Org. Lett., 19, 332 (2017). (g) J.R. Robinson, X. Fan, Y. Jagjit, P.J. Carroll, A.J. Wooten, M.A. Pericas, E.J. Schelter, P.J. Walsh. J. Am. Chem. Soc., 136, 8034 (2014). (h) Y. Mei, D.J. Averill, M.J. Allen. J. Org. Chem., 77, 5624 (2012). (i) Y. Xu, L. Lin, M. Kanai, S. Matsunaga, M. Shibasaki. J. Am. Chem. Soc., 133, 5791 (2011). (j) Y. Mei, P. Dissanayake, M.J. Allen. J. Am. Chem. Soc., 132, 12871 (2010). (k) H. Mihara, Y. Xu, N.E. Shepherd, S. Matsunaga, M. Shibasaki. J. Am. Chem. Soc., 131, 8384 (2009). (1) L. Xiang, Q. Wang, H. Song, G. Zi. Organometallics, 26, 5323 (2007). (m) D.V. Gribkov, K.C. Hultzsch, F. Hampel. J. Am. Chem. Soc., 128, 3748 (2006). (n) N. Yamagiwa, H. Qin, S. Matsunaga, M. Shibasaki. J. Am. Chem. Soc., 127, 13419 (2005). (o) T. Hamada, K. Manabe, S. Ishikawa, S. Nagayama, M. Shiro, S. Kobayashi. J. Am. Chem. Soc., 125, 
2989 (2003). (p) H. Kodama, J. Ito, K. Hori, T. Ohta, I. Furukawa. J. Organomet. Chem., 603, $6(2000)$.

[4] (a) G. Desimoni, G. Faita, P. Quadrelli. Chem. Rev., 103, 3119 (2003). (b) B.D. Ward, L.H. Gade. Chem. Commun., 48, 10587 (2012). (c) H.C. Aspinall, N. Greeves. J. Organomet. Chem., 647, 151 (2002). For other interesting applications (luminiscence) of Ln-pyBOX complexes see: (d) A. de Bettencourt-Dias, S. Viswanathan, A. Rollett. J. Am. Chem. Soc., 129, 15436 (2007). (e) A. de Bettencourt-Dias, P.S. Barber, S. Viswanathan, D.T. de Lill, A. Rollett, G. Ling, S. Altun. Inorg. Chem., 49, 8848 (2010). (f) K. Matsumoto, K. Suzuki, T. Tsukuda, T. Tsubomura. Inorg. Chem., 49, 4717 (2010).

[5] (a) S. Chorazy, K. Nakabayashi, M. Arczynski, R. Pelka, S. Ohkoshi, B. Sieklucka. Chem. Eur. J., 20, 7144 (2014). (b) T. Harada, H. Tsumatori, K. Nishiyama, J. Yuasa, Y. Hasegawa, T. Kawai. Inorg. Chem., 51, 6476 (2012). (c) A. Bettencourt-Dias, P.S. Barber, S. Bauer. J. Am. Chem. Soc., 134, 6987 (2012).

[6] (a) A. Pericas, R. Jimenez, A. Granados, A. Shafir, A. Vallribera, A. Roglans, E. Molins. ChemistrySelect, 1, 4305 (2016). (b) J. Comelles, A. Pericas, M. Moreno-Manas, A. Vallribera, G. Drudis-Sole, A. Lledos, T. Parella, A. Roglans, S. Garcia-Granda, L. Roces-Fernandez. J. Org. Chem., 72, 2077 (2007).

[7] (a) M.T. Barros, A.M.F. Phillips. Tetrahedron: Asymmetry, 21, 2746 (2010). (b) H. Suga, S. Higuchi, M. Ohtsuka, D. Ishimoto, T.Arikawa, Y. Hashimoto, S. Misawa, T. Tsuchida, A. Kakehi, T. Baba. Tetrahedron, 66, 3070 (2010). (c) H. Suga, K. Inoue, S. Inoue, A. Kakehi, M. Shiro. J. Org, Chem., 70, 47 (2005). (d) H. Suga, K. Inoue, S. Inoue, A. Kakehi. J. Am. Chem. Soc., 124, 14836 (2002). (e) A.I. Sanchez-Blanco, K.V. Gothelf, K.A. Jørgensen. Tetrahedron Lett., 38, 7923 (1997).

[8] (a) G. Desimoni, G. Faita, M. Mella, F. Piccinini, M. Toscanini. Eur. J. Org., 1529 (2017). (b) G. Desimoni, G. Faita, M. Guala, A. Laurenti, M. Mella. Chem. Eur. J., 11, 3816 (2005). (c) G. Desimoni, G. Faita, M. Guala, C. Pratelli. J. Org. Chem., 68, 7862 (2003).

[9] (a) G. Desimoni, G. Faita, F. Piccinini, M. Toscanini. Eur. J. Org. Chem., 5228 (2006).

(b) G. Desimoni, G. Faita, S. Filippone, M. Mella, M.G. Zampori, M. Zema. Tetrahedron, 57, 10203 (2001). 
[10] (a) H.C. Aspinall, J.F. Bickley, N. Greeves, R.V. Kelly, P.M. Smith. Organometallics, 24, 3458 (2005). (b) C. Joensson, S. Lundgren, S.J. Haswell, C. Moberg. Tetrahedron, 60, 10515 (2004). (c) G.M. Sammis, H. Danjo, E.N. Jacobsen. J. Am. Chem. Soc., 126, 9928 (2004). (d) H.C. Aspinall, N. Greeves, P.M. Smith. Tetrahedron Lett., 40, 1763 (1999).

[11] (a) U. Kazmaier. In Amino Acids, Peptides and Proteins in Organic Chemistry, A.B. Hughes (Ed.), Vol. 2, p. 3, Wiley-VCH, Weinheim (2009). (b) J. Jiang, Z. Ma, S.L. Castle. Tetrahedron, 71, 5431 (2015).

[12] (a) S. Wang, S. Zhou, W. Liu. Curr. Opin. Chem. Biol., 17, 626 (2013). (b) B. Li, L.E. Cooper, W.A. van der Donk. Methods Enzymol., 458, 533 (2009).

[13] M.A. Blaskovich. In Handbook on Syntheses of Amino Acids.General Route to Amino Acids, p. 225, ACS and Oxford University Press, New York (2010).

[14] (a) F. Palacios, J. Vicario. Org. Lett., 8, 5404 (2006). (b) L. Qiu, L. Gao, J. Tang, D. Wang, X. Guo, S. Liu, L. Yang, J. Li, W. Hu. J. Org. Chem., 79, 4142 (2014). (c) A. Lee, H. Kim. J. Am. Chem. Soc., 137, 11250 (2015).(d) M. Espinosa, A. Garcia-Ortiz, G. Blay, L. Cardona, M.C. Muñoz, J.R. Pedro. RSC Adv., 6, 15655 (2016).

[15] (a) M. Espinosa, G. Blay, L. Cardona, J.R.Pedro. Chem. Eur. J., 19, 14861 (2013). (b) M. Espinosa, G. Blay, L. Cardona, J.R. Pedro. Chem. Eur. J., 19, 17632 (2013).

[16] G.M. Sheldrick. SHELXL-2014, University of Göttingen, Germany (2014).

[17] X-ray data for compound 3bl: crystallized from hexane-EtOAc; $\mathrm{C}_{25} \mathrm{H}_{29} \mathrm{SN}_{1} \mathrm{O}_{8} ; \mathrm{Mr}=$ 503.55; triclinic; space group $=\mathrm{P} 1 ; \mathrm{a}=6.2550(2), \mathrm{b}=10.2870(4), \mathrm{c}=11.1380(5) \AA ; \alpha=$ 69.333(2), $\beta=78.688(2), \gamma=82.555(2)^{\circ} ; \mathrm{V}=656.11(5) \AA^{3} ; \mathrm{Z}=1 ; \rho_{\text {calcd }}=1.274 \mathrm{Mg} \mathrm{m}^{-3}$; $\mu=0.170 \mathrm{~mm}^{-1} ; \mathrm{F}(000)=266$. A colorless crystal of $0.04 \times 0.08 \times 0.08 \mathrm{~mm}^{3}$ was used; $5797[\mathrm{R}(\mathrm{int})=0.0682]$ total reflections were collected on a Enraf Nonius Kappa CCD equipped with a graphite monochromator and $\operatorname{Mo} \mathrm{K} \alpha(\lambda=0.71073 \AA)$ radiation. The structures were solved by using direct methods with SHELXS-2014 and refined by using full matrix least squares on $\mathrm{F}^{2}$ with SHELXL-2014 [16]. Non-hydrogen atoms were refined anisotropically and hydrogens were obtained or placed in calculated positions refined by using idealized geometries (riding model) and assigned fixed isotropic displacement parameters. Final values were $\mathrm{R}=0.0469$ and $\omega \mathrm{R}=0.1054$. CCDC1581116 contains the supplementary crystallographic data for this compound. These data 
can be obtained free of charge from the Cambridge Crystallographic Data Centre via www.ccdc.cam.ac.uk/data_request/cif.

[18] S. Parsons, H.D. Flack, T. Wagner. Acta Cryst. B, 69, 249 (2013).<smiles>[R]C1N=C(c2cccc(C3=NC([R])C([R])O3)n2)OC1[R]</smiles>

pyBOX1, $R=P h, R^{\prime}=H$ pyBOX2, $\mathrm{R}=i \mathrm{Pr}, \mathrm{R}^{\prime}=\mathrm{H}$

pyBOX3, $\mathrm{R}=\mathrm{BnCH}_{2}, \mathrm{R}^{\prime}=\mathrm{H}$ pyBOX4, $R=M e, R^{\prime}=P h$

Figure 1. pyBOX-type ligands used in this study. 


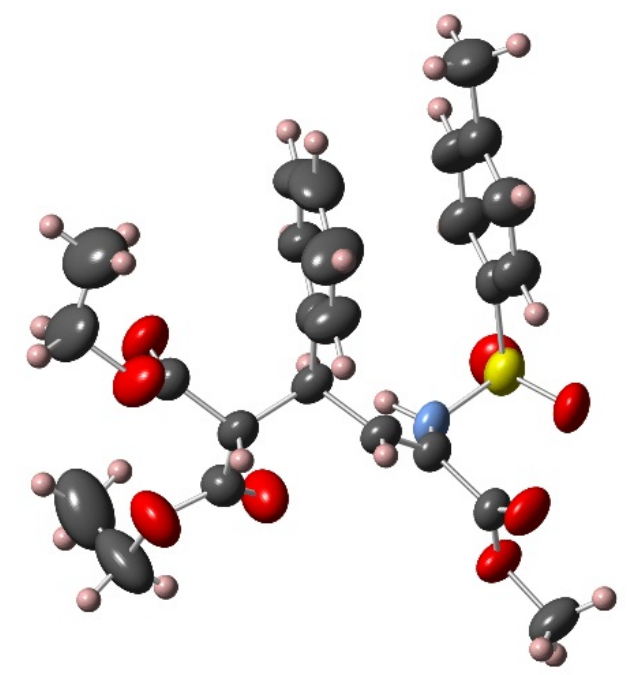

Figure 2. ORTEP plot for the X-ray structure of $\mathbf{3 b l}$. The thermal ellipsoids are drawn at the 50\% probability level.

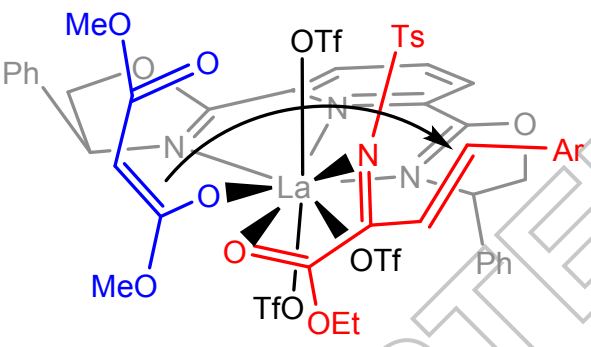

(a)

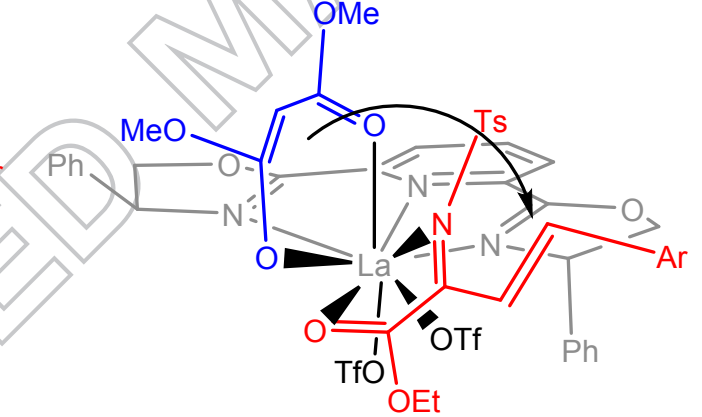

(b)

Figure 3. Proposed stereochemical model for the La(OTf $)_{3}$-pyBOX1 catalyzed enantioselective conjugate addition of methyl malonate to $\alpha, \beta$-unsaturated $\mathrm{N}$-sulfonyl imines 2. 
Table 1. Enantioselective addition of malonate esters 1 to unsaturated imine 2a catalyzed by pyBOX-M(III) complexes. ${ }^{\mathrm{a}}$

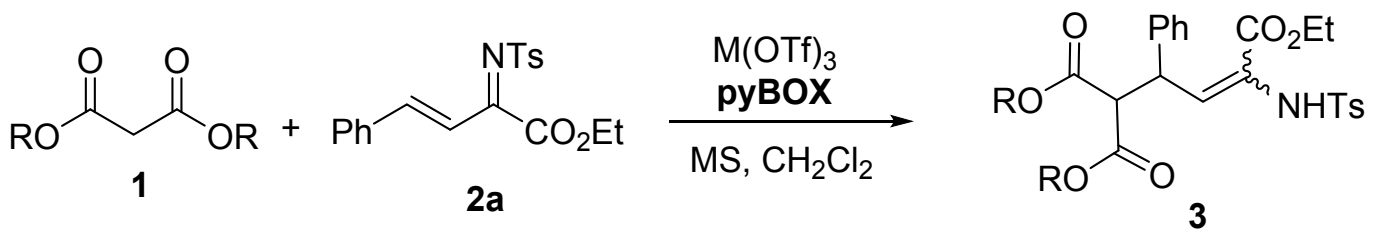

\begin{tabular}{|c|c|c|c|c|c|c|c|c|c|c|}
\hline Entry & $\mathbf{M}$ & pyBOX & 1 & $\mathbf{R}$ & Solvent & $t$ (h) & 3 & Yield $(\%)^{b}$ & $\operatorname{dr}(E / Z)^{\mathrm{c}}$ & $(\%)^{d}$ \\
\hline 1 & $\mathrm{La}$ & pyBOX1 & $1 a$ & $\mathrm{Me}$ & $\mathrm{CH}_{2} \mathrm{Cl}_{2}$ & 16 & 3aa & 94 & $2: 98$ & -86 \\
\hline 2 & $\mathrm{Yb}$ & pyBOX1 & $1 a$ & $\mathrm{Me}$ & $\mathrm{CH}_{2} \mathrm{Cl}_{2}$ & 44 & $3 \mathbf{a a}$ & 23 & & 30 \\
\hline 3 & $\mathrm{Sc}$ & pyBOX1 & $1 \mathbf{a}$ & $\mathrm{Me}$ & $\mathrm{CH}_{2} \mathrm{Cl}_{2}$ & 46 & $3 \mathbf{a a}$ & - & & - \\
\hline 4 & In & pyBOX1 & $1 \mathbf{a}$ & $\mathrm{Me}$ & $\mathrm{CH}_{2} \mathrm{Cl}_{2}$ & 46 & $3 \mathbf{a a}$ & - & & - \\
\hline 5 & $\mathrm{La}$ & pyBOX2 & $1 \mathrm{a}$ & $\mathrm{Me}$ & $\mathrm{CH}_{2} \mathrm{Cl}_{2}$ & 19 & $3 \mathbf{a a}$ & 90 & 1:99 & -52 \\
\hline 6 & $\mathrm{La}$ & руВОX3 & $1 \mathbf{a}$ & $\mathrm{Me}$ & $\mathrm{CH}_{2} \mathrm{Cl}_{2}$ & 26 & $3 \mathbf{a a}$ & 9 & $4: 96$ & -35 \\
\hline 7 & $\mathrm{La}$ & pyBOX4 & $1 \mathbf{a}$ & $\mathrm{Me}$ & $\mathrm{CH}_{2} \mathrm{Cl}_{2}$ & 19 & 3aa & 9 & $13: 87$ & 26 \\
\hline 8 & $\mathrm{La}$ & pyBOX5 & $1 \mathbf{a}$ & $\mathrm{Me}$ & $\mathrm{CH}_{2} \mathrm{Cl}_{2}$ & 26 & $3 a a$ & 94 & $13: 87$ & 16 \\
\hline $9^{e}$ & $\mathrm{La}$ & pyBOX1 & $1 \mathrm{a}$ & $\mathrm{Me}$ & $\mathrm{CH}_{2} \mathrm{Cl}_{2}$ & 16 & $3 a a$ & 98 & 7:93 & -74 \\
\hline $10^{\mathrm{f}}$ & $\mathrm{La}$ & pyBOX1 & $1 \mathrm{a}$ & $\mathrm{Me}$ & $\mathrm{CH}_{2} \mathrm{Cl}_{2}$ & 15 & $3 a$ & 92 & $8: 92$ & -73 \\
\hline 11 & $\mathrm{La}$ & pyBOX1 & $1 \mathbf{a}$ & $\mathrm{Me}$ & $\mathrm{CHCl}_{3}$ & 17 & $3 \mathbf{a a}$ & 99 & $5: 95$ & -78 \\
\hline 12 & $\mathrm{La}$ & pyBOX1 & $1 \mathbf{a}$ & $\mathrm{Me}$ & $\mathrm{DCF}$ & 17 & $3 \mathbf{a a}$ & 89 & $4: 96$ & -86 \\
\hline 13 & $\mathrm{La}$ & pyBOX1 & $1 \mathrm{a}$ & $\mathrm{Me}$ & toluene & 16 & $3 \mathbf{a a}$ & 93 & $4: 96$ & -61 \\
\hline 14 & $\mathrm{La}$ & pyBOX1 & $1 \mathbf{a}$ & $\mathrm{Me}$ & THF & 16 & $3 \mathbf{a a}$ & 99 & $2: 98$ & -83 \\
\hline 15 & $\mathrm{La}$ & pyBOX1 & $1 \mathbf{a}$ & Me & dioxane & 35 & $3 \mathbf{a a}$ & 96 & $11: 89$ & -55 \\
\hline 16 & $\mathrm{La}$ & pyBOX1 & $1 \mathbf{a}$ & & $\mathrm{Et}_{2} \mathrm{O}$ & 18 & $3 \mathbf{a a}$ & 95 & $2: 98$ & -86 \\
\hline 17 & $\mathrm{La}$ & pyBOX1 & $1 \mathrm{~b}$ & $\mathrm{Et}$ & $\mathrm{CH}_{2} \mathrm{Cl}_{2}$ & 18 & $3 \mathbf{b a}$ & 94 & 1:99 & -91 \\
\hline 18 & $\mathrm{La}$ & pyBOX1 & $1 b$ & Et & $\mathrm{Et}_{2} \mathrm{O}$ & 20 & $3 \mathbf{b a}$ & 87 & $3: 97$ & -76 \\
\hline 19 & $\mathrm{La}$ & руВOX1 & $1 c$ & $i \operatorname{Pr}$ & $\mathrm{CH}_{2} \mathrm{Cl}_{2}$ & 16 & $3 \mathbf{c a}$ & 94 & $2: 98$ & -73 \\
\hline 20 & $\mathrm{La}$ & руВOX1 & $1 \mathrm{c}$ & $i \operatorname{Pr}$ & $\mathrm{Et}_{2} \mathrm{O}$ & 15 & $3 \mathbf{c a}$ & 99 & $3: 97$ & -25 \\
\hline $21^{g}$ & $\mathrm{La}$ & pyBOX1 & $1 \mathbf{a}$ & $\mathrm{Me}$ & $\mathrm{CH}_{2} \mathrm{Cl}_{2}$ & 41 & $3 \mathbf{a a}$ & 94 & $5: 95$ & -87 \\
\hline $22^{g}$ & $\mathrm{La}$ & pyBOX1 & $1 b$ & $\mathrm{Et}$ & $\mathrm{CH}_{2} \mathrm{Cl}_{2}$ & 64 & $3 \mathbf{b a}$ & 93 & 1:99 & -86 \\
\hline $23^{\mathrm{h}}$ & $\mathrm{La}$ & - & $1 \mathrm{a}$ & $\mathrm{Me}$ & $\mathrm{CH}_{2} \mathrm{Cl}_{2}$ & 24 & $3 \mathbf{a a}$ & 80 & $74: 26$ & - \\
\hline
\end{tabular}

a Reaction conditions: 1 (0.6 mmol), 2a $(0.25 \mathrm{mmol})$, pyBOX $(0.025 \mathrm{mmol}), \mathrm{M}(\mathrm{OTf})_{3}$ (0.025 mmol), $4 \AA \mathrm{MS}(110 \mathrm{mg})$, solvent $(2.2 \mathrm{~mL}) .{ }^{\mathrm{b}}$ Yield of isolated product.

c Determined by ${ }^{1} \mathrm{H}$ NMR. ${ }^{\mathrm{d}}$ Only for the major $(Z)$-diastereomer. Determined by HPLC with chiral stationary phases; opposite sign indicates opposite enantiomers. ${ }^{\mathrm{e}} 3 \AA \mathrm{MS}$ was used. ${ }^{\mathrm{f}} 5 \AA \mathrm{MS}$ was used. ${ }^{\mathrm{g}}$ Reaction carried out at $0{ }^{\circ} \mathrm{C}$. ${ }^{\mathrm{h}}$ Reaction carried out at $40{ }^{\circ} \mathrm{C}$. 
Table 2. Enantioselective addition of dialkyl malonates to unsaturated imines $\mathbf{2}$ catalyzed by pyBOX1-La(OTf) ${ }_{3}{ }^{a}$

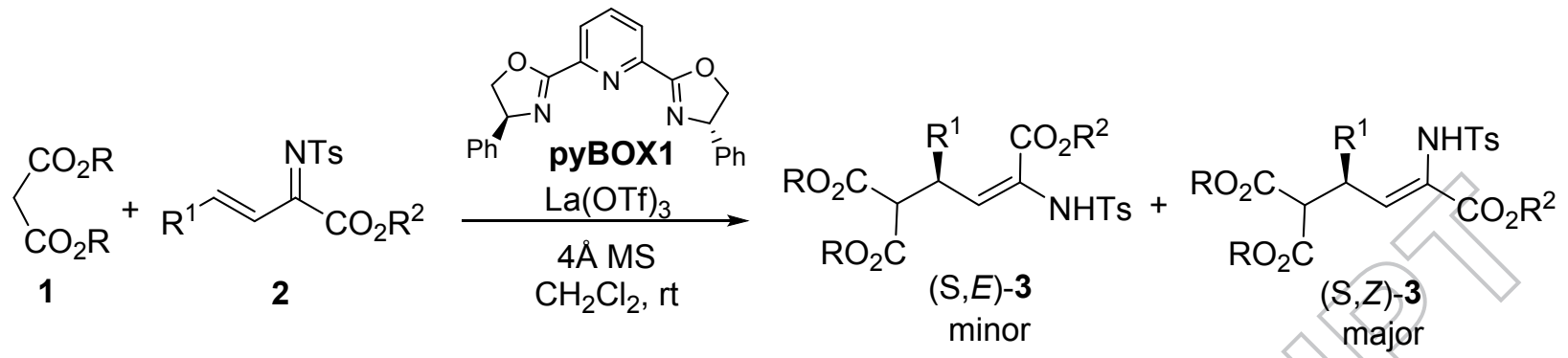

\begin{tabular}{|c|c|c|c|c|c|c|c|c|c|c|}
\hline Entry & 1 & $\mathbf{R}$ & 2 & $\mathbf{R}^{1}$ & $\mathbf{R}^{2}$ & $t(\mathbf{h})$ & 3 & Yield $(\%)^{b}$ & $\operatorname{dr}(E / Z)^{\mathfrak{e}}$ & ee $(E / Z)^{d}$ \\
\hline 1 & $1 b$ & $\mathrm{Et}$ & $2 a$ & $\mathrm{Ph}$ & $\mathrm{Et}$ & 18 & $3 \mathbf{b a}$ & 94 & $1: 99$ & $7 / 91$ \\
\hline 2 & $1 b$ & Et & $2 b$ & 4- $\mathrm{MeC}_{6} \mathrm{H}_{4}$ & $\mathrm{Et}$ & 39 & $3 b b$ & 99 & $1: 99$ & $-/ 88$ \\
\hline 3 & $1 b$ & Et & $2 c$ & $4-\mathrm{ClC}_{6} \mathrm{H}_{4}$ & Et & 30 & $3 b c$ & 97 & $6: 94$ & $21 / 88$ \\
\hline 4 & $1 b$ & Et & $2 d$ & $4-\mathrm{NO}_{2} \mathrm{C}_{6} \mathrm{H}_{4}$ & Et & 72 & $3 b d$ & & $5: 95$ & $24 / 69$ \\
\hline 5 & $1 b$ & Et & $2 e$ & $4-\mathrm{MeOC}_{6} \mathrm{H}_{4}$ & $\mathrm{Et}$ & 39 & 3be & 99 & $1: 99$ & $22 / 86$ \\
\hline 6 & $1 b$ & Et & $2 f$ & $3-\mathrm{ClC}_{6} \mathrm{H}_{4}$ & $\mathrm{Et}$ & 39 & $3 b f$ & 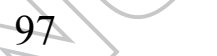 & $1: 99$ & $44 / 90$ \\
\hline 7 & $1 b$ & Et & $2 \mathrm{~g}$ & $3-\mathrm{NO}_{2} \mathrm{C}_{6} \mathrm{H}_{4}$ & $\mathrm{Et}$ & 72 & $3 b g$ & 99 & $7: 93$ & $38 / 52$ \\
\hline 8 & $1 b$ & $\mathrm{Et}$ & $2 h$ & $3-\mathrm{MeOC}_{6} \mathrm{H}_{4}$ & $\mathrm{Et}$ & 43 & $3 b h$ & 91 & $7: 93$ & $37 / 88$ \\
\hline 9 & $1 b$ & Et & $2 \mathbf{i}$ & $2-\mathrm{ClC}_{6} \mathrm{H}_{4}$ & $\mathrm{Et}$ & 72 & $3 b i$ & 99 & $2: 98$ & $23 / 95$ \\
\hline 10 & $1 b$ & Et & $2 \mathbf{j}$ & $2-\mathrm{NO}_{2} \mathrm{C}_{6} \mathrm{H}_{4}$ & $\mathrm{Et}$ & 120 & $3 \mathbf{b j}$ & 95 & $29: 71$ & $60 / 20$ \\
\hline 11 & $1 b$ & Et & $2 \mathbf{k}$ & 2-furanyl & $\mathrm{Et}$ & 63 & $3 b \mathbf{b}$ & 93 & $2: 98$ & $7 / 84$ \\
\hline 12 & $1 b$ & Et & 21 & $\mathrm{Ph}$ & $\mathrm{Me}$ & 21 & $3 b l$ & 99 & $1: 99$ & $14 / 87$ \\
\hline 13 & $1 b$ & $\mathrm{Et}$ & $2 \mathrm{~m}$ & $\mathrm{Ph}$ & $i \operatorname{Pr}$ & 20 & $3 b m$ & 98 & 1:99 & $44 / 89$ \\
\hline 14 & $1 \mathbf{a}$ & $\mathrm{Me}$ & $2 a$ & $\mathrm{Ph}$ & Et & 16 & $3 \mathbf{a a}$ & 94 & $2: 98$ & $2 / 86$ \\
\hline 15 & $1 c$ & $i \operatorname{Pr}$ & $2 a$ & $\mathrm{Ph}$ & $\mathrm{Et}$ & 16 & $3 c a$ & 94 & $3: 97$ & $83 / 73$ \\
\hline
\end{tabular}

a Reaction conditions: 1 (0.6 mmol), $2(0.25 \mathrm{mmol})$, pyBOX1 $(0.025 \mathrm{mmol}), \mathrm{La}(\mathrm{OTf})_{3}$ $(0.025 \mathrm{mmol}), 4 \AA \mathrm{MS}(110 \mathrm{mg})$, solvent $(2.2 \mathrm{~mL}), \mathrm{rt}^{\mathrm{b}}{ }^{\mathrm{b}}$ Yield of isolated product.

${ }^{\mathrm{c}}$ Determined by $1 \mathrm{H}$ NMR. ${ }^{\mathrm{d}}$ Determined by HPLC with chiral stationary phases.

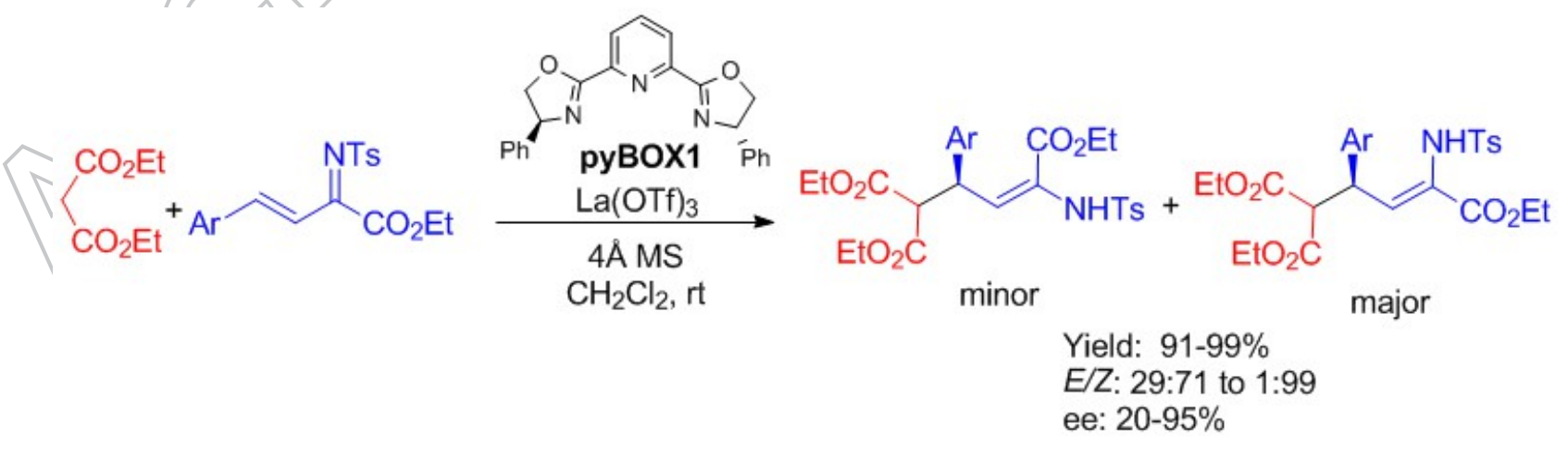

